\title{
100 år med vitamin
}

«Vitamin» er et av få ord der både opphavsår og opphavsmann er kjent. Det er i år 100 år siden ordet ble laget.

Vitaminer er essensielle organiske forbindelser, som må tilføres kroppen i små mengder. I dag kjenner man 13 ulike vitaminer, som gjerne inndeles i to hovedgrupper: de fettløselige vitaminene A, D, $\mathrm{E}$ og $\mathrm{K}$, og de vannløselige, som omfatter vitaminene i B-komplekset og vitamin C.

Det var den polskfødte biokjemikeren Casimir (egentlig Kazimierz) Funk (1884-1967) som fant på navnet. Han satte sammen det latinske «vita», som betyr liv, og den kjemiske betegnelsen «amin». Vitamin betyr altså direkte oversatt «livsviktig amin».

\section{De første årene}

I kildene gis litt ulike opplysninger om når ordet ble laget. Noen mener $1911(1,2)$,

\section{THE VITAMINES}
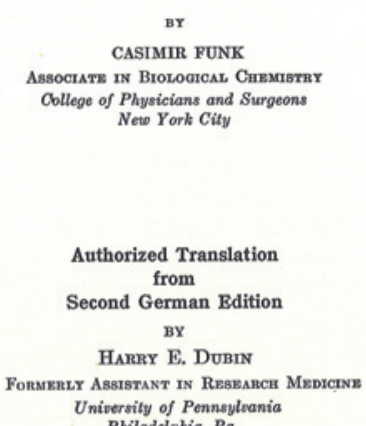

Philadelphia, Pa.

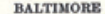

WILLIAMS \& WILKINS COMPANY

1922

Ordet «vitamin» ble en umiddelbar suksess. Casimir Funk skrev at han han ønsket et navn «that would sound well and serve as a catchword» (16). Faksimile fra boken andre oppgir 1912 (3-5), atter andre 1913 (6-8). Etter alt å dømme er 1912 riktig. Casimir Funk brukte begrepet $i$ to artikler dette året, mens han arbeidet ved Lister Institute i London. Den mest kjente sto i tidsskriftet The Journal of State Medicine: «It is now known that all these diseases, with the exception of pellagra, can be prevented and cured by the addition of certain preventive substances; the deficient substances, which are of the nature of organic bases, we will call «vitamines»; and we will speak of a beri-beri or scurvy vitamine, which means, a substance preventing the special disease» (9). I Journal of Physiology senere på året skrev han: «I have suggested the name vitamine for it as being one of the nitrogenous substances, minute quantities of which are essential in the diet of birds, men and some other animals» (10). Ordet kom forbausende hurtig i bruk, også blant folk flest $(11,12)$.

Ettersom det ikke fantes støtte for Funks opprinnelige idé om at vitaminene var aminer, foreslo den britiske biokjemikeren Jack Drummond (1891-1952) i 1920 at e-en til slutt i ordet burde fjernet. Dermed ble «vitamin» stående, og slik skrives det fremdeles (13). Drummond foreslo også at vitaminene skulle benevnes med bokstaver, og slik ble det.

\section{Funks rolle}

Det er ingen uenighet om at det var Funk som fant på navnet vitamin. Hvem som «oppdaget» vitaminene er det imidlertid vanskeligere å svare på. De fleste vitaminene ble identifisert i perioden 1920-40 (12). I 1929 hadde man kommet frem til at det var på tide å tildele nobelprisen i fysiologi eller medisin til oppdagerne (14). Men hvem var det? Funk var blitt foreslått, men det endte med at prisen ble delt mellom nederlenderen Christiaan Eijkman (1858-1930) og briten Frederick Hopkins (1861-1947). I nobelforedraget sitt gjorde Hopkins rede for Funks bidrag, og konkluderte på følgende måte: «he has not received too much, but too little, credit for his vitamin work» (15).

\section{Erlend Hem}

erlend.hem@medisin.uio.no

Erlend Hem (f. 1970) er dr.med. og assisterende redaktør i Tidsskriftet.

Litteratur

1. Bull F, Eskeland A, Tandberg E, red. Gyldendals store konversasjonsleksikon. 3. utg. Bd. 5. Oslo: Gyldendal, 1972: 3601

2. Haubrich WS. Medical meanings: a glossary of word origins. Philadelphia, PA: American College of Physicians, 1997: 245

3. Jacobsen $H G$, Jensen $H$, Jørgensen PS. Politikens ord med historie. København: Politikens forlag 1994: 274-5

4. Den Danske Ordbog. http://ordnet.dk/ddo/ ordbog?query=vitamin $(29.11 .2011)$

5. Oxford English Dictionary. 2. utg. 1989 http://oed.com/view/Entry/224034 (30.11.2011).

6. Bokmålsordboka og Nynorskordboka. www.nob-ordbok.uio.no/perl/ ordbok.cgi?OPP=vitamin $(29.11 .2011)$

7. Knudsen T, Sommerfelt A, Noreng H, red. Norsk riksmålsordbok. Bd. 4. Oslo: Kunnskapsforlaget, 1983: 4015

8. Salmonsens konversationsleksikon. 2. utg. Bd. 25. København: J.H. Schultz, 1928: 295 http://runeberg.org/salmonsen/2/25/0303.html (29.11.2011).

9. Funk $C$. The etiology of the deficiency diseases. J State Med 1912; 20: 341-68. www.ltdk.helsinki.fi/users/hemila/History/ Funk_1912.pdf (29.11.2011)

10. Funk $C$. The preparation from yeast and certain foodstuffs of the substance the deficiency of which in diet occasions polyneuritis in birds. J Physiol 1912; 45: 75-81. www.ncbi.nlm.nih.gov/pmc/ articles/PMC1512873 (29.11.2011).

11. Hardy A. Historical keywords: Vitamin. Lancet 2004; 364: 323

12. Rosenberg HR. The fiftieth anniversary of Casimir Funk's «vitamins». Nutr Rev 1962; 20: 353-5.

13. Rosenfeld L. Vitamine - vitamin. The early years of discovery. Clin Chem 1997; 43: 680-5. www. clinchem.org/cgi/reprint/43/4/680 (29.11.2011).

14. Carpenter KJ. The Nobel Prize and the discovery of vitamins. www.nobelprize.org/nobel_prizes/ medicine/articles/carpenter (29.11.2011).

15. Sir Frederick Hopkins - Nobel Lecture. www.nobelprize.org/nobel_prizes/medicine/ laureates/1929/hopkins-lecture.html (29.11.2011)

16. Funk $C$. The vitamines. The classics of medicine library. New York: Gryphon, 1997: 36. Faksimileutg. Opprinnelig utg.: Baltimore: Williams \& Wilkins, 1922.

Mottatt 30.11.2011 og godkjent 1.12. 2011. Medisinsk redaktør Raida Ødegaard. 